\title{
Afroaltica subaptera, new genus and new species of flea beetles from the southern Africa (Coleoptera: Chrysomelidae: Alticinae)
}

\author{
Maurizio BIONDI and PaOla D’ALESSANDRO
}

Dipartimento di Scienze Ambientali, University of L'Aquila, 67010 Coppito (AQ), Italy; e-mail: biondi@univaq.it

Key words. Taxonomy, Coleoptera, Chrysomelidae, Alticinae, Afroaltica, new genus, new species, Afrotropical region

\begin{abstract}
Afroaltica subaptera, a new genus and species of flea beetles (Chrysomelidae: Alticinae) from the eastern regions of southern Africa (Eastern Transvaal and Kwazulu-Natal), is described. Afroaltica gen. n. shows some similarities with the genus Dibolia Latreille, 1829 but it is easily distinguishable mainly by the simple-shaped apical spur of hind tibiae, not bifid. External habitus, scanning electronic micrographs of particular morphological features and line drawings of metafemoral spring and male and female genitalia of the new taxon are provided.
\end{abstract}

\section{INTRODUCTION}

The Alticinae (Coleoptera: Chrysomelidae) is a subfamily composed of minute-to-medium sized beetles whose enlarged hind femora and renowned jumping ability have earned the common name of "flea beetles". They are highly specialized phytophagous insects, widespread in all the zoogeographical regions. Both adult and larval stages feed on stems, leaves or roots, more rarely on flowers, in almost all higher plant families. The world fauna of this subfamily is represented by approximately 9000 species and 500 genera described (Petitpierre, 2000).

The flea beetle fauna from the Afrotropical region is still very poorly known. At the moment, it includes, considering also Madagascar, about 100 genera and 1600 species (Scherer, 1961; Biondi, unpubl. data).

During recent collecting trips made by one of us (Biondi) in the Republic of South Africa, many specimens of a singular-shaped flea beetle were collected in several sites of the Eastern Transvaal and Kwazulu-Natal provinces. After a brief inspection we realized that these specimens possessed some important morphological features attributable to a new genus, described in this paper.

\section{MATERIAL AND METHODS}

Studied material of this new taxon mainly consists of preserved dry insects from collection of the senior author and two specimens provided to us by courtesy of the institution ZMHB. The specimens were examined and dissectioned using WILD MZ8 and MZ12.5 binocular microscopes. Microscope photos were taken by a Leica DFC500 camera. Scanning electron micrographs were taken by a PHILIPS SEM XL30 CP. Line drawings were performed using the graphics software CorelDRAW vers. 10.

\section{Abbreviations}

Morphology. LAED - length of median lobe of aedeagus; LAN - length of antenna; LE - length of elytron; LP - length of pronotum; LSP - length of spermatheca; WE - width of elytra; WP - width of pronotum.

\section{Collections and depositories}

BAQ - collection of the author, Dipartimento di Scienze Ambientali, University of L'Aquila, Italy; BMNH - The Natural History Museum, London, United Kingdom; MRAC: Musée Royal de l'Afrique Centrale, Tervuren, Belgium; NHMB: Naturhistorisches Museum, Basel, Switzerland; SANC: South African National Collection, Plant Protection Research Institute, Pretoria, Gauteng, Republic of South Africa; TMSA: Transvaal Museum, Pretoria, Gauteng, Republic of South Africa; ZMHB: Museum für Naturkunde der Humboldt-Universität, Berlin, Germany.

\section{RESULTS}

\section{Afroaltica gen. n.}

Diagnosis. Afroaltica gen. n. occupies a rather isolated position within the subfamily Alticinae. The new genus shows some morphological similarities with the genus Dibolia Latreille, 1829, widespread in the most parts of the world, such as a compact, elliptical, moderately elongate and strongly convex body shape (Fig. 2), metafemoral spring structure (Fig. 14) and procoxal cavities posteriorly open (Fig. 12). However, Afroaltica gen. $\mathrm{n}$. is easily distinguishable by having: apical spur of hind tibiae simple, not bifid; antennae short, enlarged in distal half (Fig. 2); an evident furrow laterally to clypeus locating first antennomere in resting position (Figs 3-4); all tibiae, especially hind tibiae, dorsally channelled and distally strongly enlarged (Figs 2, 9); middle tibiae in male with an evident hollow, probably sensorial, on ventral side (Fig. 10).

Description. Body shape compact, elliptical, moderately elongate and strongly convex; head hypognatous, largely inserted in pronotum; antennae relatively short in both sexes but gradually and clearly enlarged from base to apex (Fig. 2); segment 1 as long as 2 and 3 together, segments 2-10 subequal in length, segments 8-10 subglobose, segment 11 asymmetrical; interantennal space wide, not raised (Fig. 3); frontal tubercles finely delimited, subtriangular, with smooth surface, sometimes partially punctulated (Fig. 3); small evident circular-shaped 


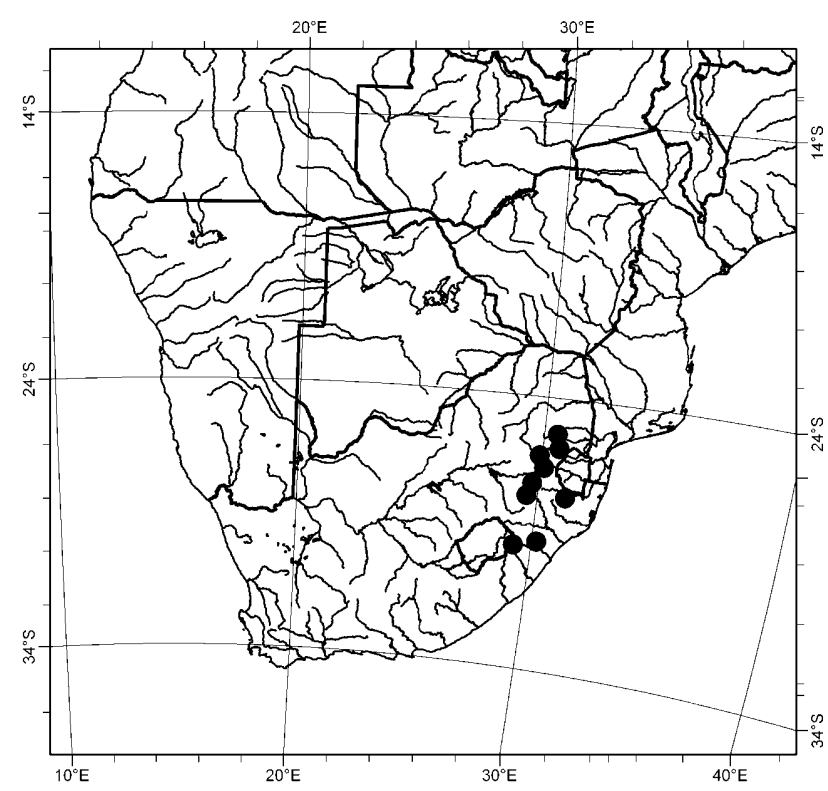

Fig. 1. Distribution map of Afroaltica subaptera sp. $\mathrm{n}$.

hollow, medially with a short seta, near upper inner ocular margin (Fig. 5); eyes small, subelliptical (Fig. 3); clypeus laterally with an evident furrow locating first antennomere in resting position (Figs 3-4); labrum subrectangular, with sinuous distal margin (Fig. 3); maxillary palpi triarticulate; labial palpi biarticulate (Fig. 6). Pronotum strongly convex, distally and basally widely protruded (Figs 2, 7); anterior angles subrounded; posterior angles widely rounded. Elytra without humeral callus, with punctation entirely confused (Figs 2,8 ); epipleura well visible almost up to apex; procoxal cavities posteriorly open (Fig. 12); prosternum with narrow intercoxal process (Fig. 12); metasternum very short (Fig. 13); hind femora strongly enlarged; all tibiae, particularly middle and hind tibiae, dorsally clearly channelled and strongly enlarged from base to apex (Figs 2, 9); apical spur of hind tibiae simple; middle tibiae in male with an evident hollow, probably sensorial, on ventral side (Fig. $10)$; third tarsomere of all legs wide, heart-shaped, weakly incised (Fig. 11); unguiculi simple (Fig. 11); median lobe of aedeagus without particular morphological characteristics (Fig. 15); spermatheca of "alticinae type" ("Type A" of Furth \& Suzuki, 1994) with basal part subcylindrical, distal part very developed; ductus of spermatheca uncoiled (Fig. 16); metafemoral spring attributable to the "Psylliodes Morpho-Group" (cf. Furth \& Suzuki, 1998) with a short and strongly depressed extended arm of dorsal lobe; dorsal edge of ventral lobe straight and angled down apically; flat spring basal edge forming almost a right angle with central axis of dorsal lobe; recurve flange very distinctly sclerotized; basal angle of ventral lobe very acute, pointed and elongate (Fig. 14).

Type species. Afroaltica subaptera sp. $\mathrm{n}$.

Etymology. This genus name refers to the geographic region where it lives and means "flea beetle from Africa".
Geographical distribution. Republic of South Africa: Eastern Transvaal and Kwazulu-Natal provinces (Fig. 1).

\section{Afroaltica subaptera sp. n.}

Type material. Holotype: $\hat{\sigma}$, South Africa, Natal, Karkloof area, $\quad 1350-1500 \mathrm{~m}, \quad 29^{\circ} 17^{\prime} \mathrm{S}, \quad 30^{\circ} 21^{\prime} \mathrm{E}$ (forest edge), 10.xii.1995, M. Biondi leg. (SANC). Paratypes: South Africa, Natal, Karkloof area, 1350-1500 m, 29 $17^{\circ} \mathrm{S}, 30^{\circ} 21^{\prime} \mathrm{E}$ (forest edge), 10.xii.1995, M. Biondi leg., 10 (BAQ); South Africa, Eastern Transvaal, $33 \mathrm{~km}$ E of Ermelo (R65), $1700 \mathrm{~m}, 26^{\circ} 34^{\prime} \mathrm{S}$, $30^{\circ} 17^{\prime} \mathrm{E}$ (road side), 13.xii.1995, M. Biondi leg., $12{ }^{\hat{0}}, 18$ 우 (BAQ, SANC, TMSA); South Africa, Eastern Transvaal, $20 \mathrm{~km}$ $\mathrm{S}$ Amersfoort, $1650 \mathrm{~m}, 27^{\circ} 10^{\prime} \mathrm{S}, 2^{\circ} 52^{\prime} \mathrm{E}$, (road side), 13.xii.1995, M. Biondi leg., 3 ô, 3 ㅇ (BAQ); ditto, A. De Biase leg., 1 ( $\mathrm{BAQ}$ ); South Africa, Transvaal, Schoemanskloof Valley, $1200 \mathrm{~m}, 25^{\circ} 19^{\prime} \mathrm{S}, 30^{\circ} 40^{\prime} \mathrm{E}, 14 . x i .1988$, E. Colonnelli leg., 40, 4 (BAQ); South Africa, Eastern Transvaal, $10 \mathrm{~km} \mathrm{SW}$ Carolina (R36), $1600 \mathrm{~m}, 26^{\circ} 08^{\prime} \mathrm{S}, 30^{\circ} 03^{\prime} \mathrm{E}$ (road side), 14.xii.1995, M. Biondi leg., 20ิ, 2 q (BAQ); South Africa, Eastern Transvaal, Nelshoogte Pass, $1300-1600 \mathrm{~m}, 25^{\circ} 49^{\prime} \mathrm{S}$, $30^{\circ} 48^{\prime} \mathrm{E}$ (forest edge), 14.xii.1995, M. Biondi leg., 10, 1 우 (BAQ); South Africa, Natal/Free State, Botha's Pass, 1500-1750 m, 273' $\mathrm{S}, 29^{\circ} 42^{\prime} \mathrm{E}$ (free state), 13.xii.1995, M. Biondi leg., 23 ô, 10 우 (BAQ, BMNH, MRAC, NHMB); South Africa, Kwazulu-Natal, Itala Game Reserve, Lowsburg, [27 $\left.34^{\prime} \mathrm{S}, 31^{\circ} 17^{\prime} \mathrm{E}\right]$ (geographical coordinates added by the authors), 10-23.xii.1992, F. Koch leg., 1 \% (ZMHB); South Africa, Kwazulu-Natal, Drakensberg, Monks Cowl, $1400 \mathrm{~m}$, $29^{\circ} 03^{\prime} \mathrm{S}, 2^{\circ} 24^{\prime} \mathrm{E}$, 9.xii.1993, F. Koch leg, $10^{\star}$ (ZMHB) (Fig. $1)$.

Description. Holotype ( $₫$ ): body shape (Fig. 2) ovalelongate; maximum pronotal width near base: $1.34 \mathrm{~mm}$; maximum elytral width at basal fifth: $1.64 \mathrm{~mm}$. Dorsal integument reddish brown, with head and most part of elytra clearly piceous. Head (Fig. 3) strongly and densely punctated on vertex and frons; surface finely microreticulate; frontal sulci not visible; small evident circularshaped hollow, medially with a short seta, near upper inner ocular margin (Fig. 5); frontal tubercles finely delimited, subtriangular, with smooth surface (Fig. 3); interantennal space as wide as length of $1^{\text {st }}$ antennomere; eyes small, elliptical (Fig. 3); frontal carina wide, not raised (Fig. 3); clypeus subtrapezoidal, with subrugose and clearly pubescent surface, laterally with an evident furrow locating first antennomere in resting position (Figs 3-4); labrum reddish, subrectangular, apically weakly incised in middle (Fig. 3); maxillary palpi piceous; antennae (Fig. 2) short (LAN = $1.48 \mathrm{~mm}$; LAN/LB = 0.49 ), with segments $1-3$ reddish brown, 4-5 partially obscured, 6-11 decisively blackened; antennomeres 7-10 clearly subglobose; length of each antennal segment proportional to numerical sequence $21: 15: 12: 9: 10: 11$ : $13: 14: 13: 14: 21(1=0.01 \mathrm{~mm})$.

Pronotum (Figs 2, 7) transverse, suboctagonal (LP = $1.07 \mathrm{~mm}$; WP/LP $=1.25$ ), with widely protruded anterior and basal parts, basally wider, laterally rounded and convergent from middle to apex; lateral and basal margin very finely bordered; anterior angles subrounded; posterior angles very widely rounded (wideness about $114^{\circ}$ ); punctation strongly, densely and uniformly impressed on very finely punctulated surface, apparently smooth. 

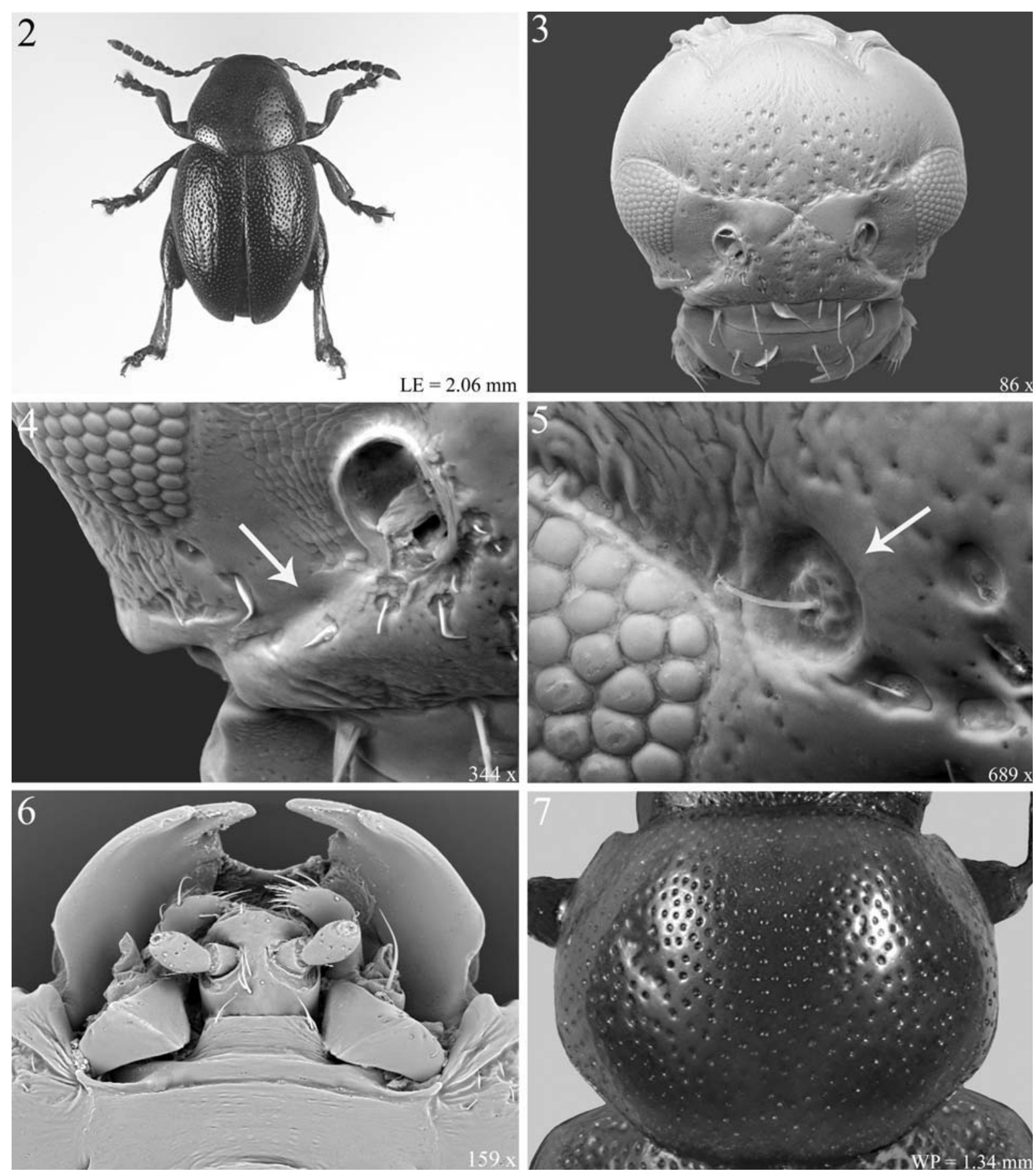

Figs 2-7. Habitus and morphological characters in Afroaltica subaptera sp. n.: habitus of the holotype ot (2); head (3); furrow locating first antennomere in resting position (4); circular-shaped hollow with middle short seta near upper inner ocular margin (5); mouthparts in ventral view (6); pronotum (7).

Elytra (Figs 2,8$)$ elongate $(\mathrm{LE}=2.06 \mathrm{~mm} ; \mathrm{LE} / \mathrm{LP}=$ 1.92 ), apically almost separately rounded and partially covering pygidium, laterally moderately rounded and clearly convergent from basal third to apex; punctation very similar to pronotal one, not arranged in rows, homogeneously distributed and strongly impressed on very finely punctulated surface; pronotal and elytral surface apparently hairless but really with very short pubescence not visible to binocular microscope (Fig. 8); humeral callus absent; metathoracic wings vestigial, without vena- tions, subapterous. Scutellum strongly transverse, halfroundish, with smooth and impunctate surface, generally not visible since covered by pronotum.

Legs mostly reddish brown, with hind femora and proximal half of hind tibiae partially dark brown; hind apical tibial spur moderately elongate, piceous, centrally inserted; $1^{\text {st }}$ anterior and middle tarsomere subtriangular, moderately enlarged; middle tibiae distinctly larger than anterior, with an evident elongate hollow, probably sensorial, excavated on inner side of distal half (Fig. 10). 

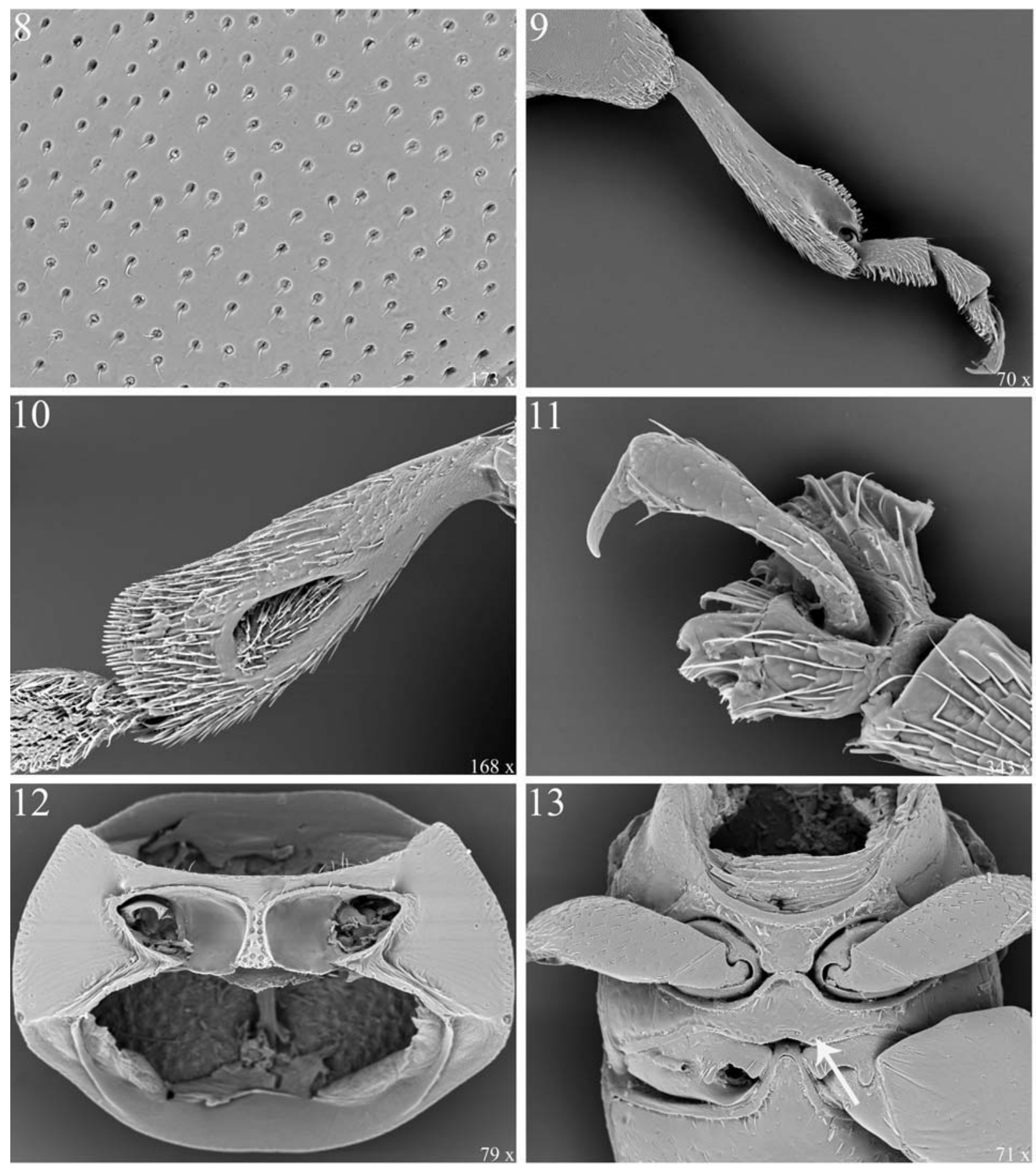

Figs 8-13. Morphological characters in Afroaltica subaptera sp. n.: elytral surface (8); right hind tibia (9); sensorial hollow on inner side of male middle tibia (10); anterior tarsomeres with simple unguiculum (11); prosternum and procoxal cavities (12); metasternum (13).

Ventral integument reddish brown, weakly obscured on abdomen; last sternite without special preapical impression but with subrugose and pubescent surface.

Median lobe of aedeagus (Fig. 15) clearly thickset $(\mathrm{LAED}=0.84 \mathrm{~mm} ; \mathrm{LE} / \mathrm{LAED}=2.45)$, with smooth surface; in ventral view distinctly tapered from base to apex; distal part slightly lanceolate apically, without any evident median small tooth; ventral sulcus very weakly excavated, more evident in apical part; dorsal ligula wide, apically subtruncate; in lateral view, median lobe moder- ately arcuate in basal third and rather straight in distal $2 / 3$ s.

Variation. $\hat{o}(\mathrm{n}=10$; mean and standard deviation): $\mathrm{LP}+\mathrm{LE}=2.83 \pm 0.49 \mathrm{~mm} ; \mathrm{LAN}=1.38 \pm 0.19 \mathrm{~mm} ; \mathrm{LP}=$ $0.97 \pm 0.20 \mathrm{~mm} ; \mathrm{WP}=1.20 \pm 0.22 \mathrm{~mm} ; \mathrm{LE}=1.86 \pm 0.30$ $\mathrm{mm} ; \mathrm{WE}=1.41 \pm 0.24 \mathrm{~mm} ; \mathrm{LAED}=0.82 \pm 0.06 \mathrm{~mm}$; $\mathrm{LAN} /(\mathrm{LP}+\mathrm{LE})=0.49 \pm 0.03 ; \mathrm{WP} / \mathrm{LP}=1.24 \pm 0.06$; $\mathrm{LE} / \mathrm{LP}=1.93 \pm 0.14 ; \mathrm{LE} / \mathrm{LAED}=2.26 \pm 0.21$. $q(\mathrm{n}=$ 10): $\mathrm{LP}+\mathrm{LE}=3.36 \pm 0.39 \mathrm{~mm} ; \mathrm{LAN}=1.40 \pm 0.16 \mathrm{~mm}$; $\mathrm{LP}=1.07 \pm 0.12 \mathrm{~mm} ; \mathrm{WP}=1.42 \pm 0.18 \mathrm{~mm} ; \mathrm{LE}=2.29$ 

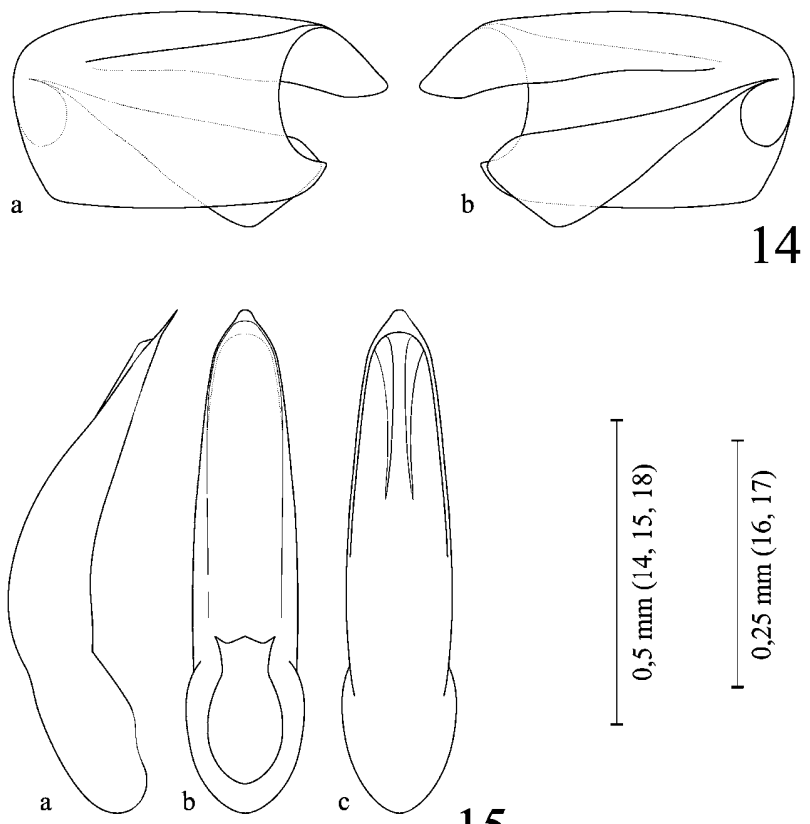

15
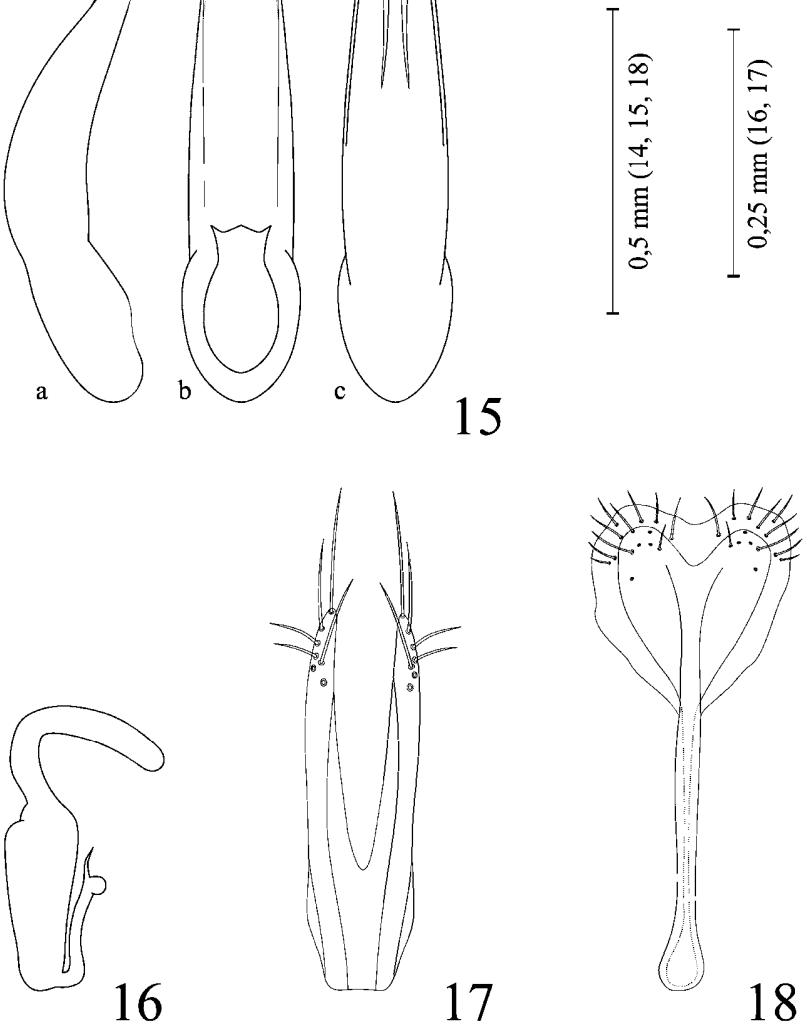

Figs 14-18. Morphological characters in Afroaltica subaptera sp. n.: right metafemoral spring (14): inner side (a) and outer side (b); lateral (a), ventral (b) and dorsal view (c) of median lobe of aedeagus (15); spermatheca (16); styli (17) and spiculum ventrale with $8^{\text {th }}$ abdominal segment (18).

$\pm 0.27 \mathrm{~mm} ; \mathrm{WE}=1.76 \pm 0.26 \mathrm{~mm} ; \mathrm{LSP}=0.25 \pm 0.02$ $\mathrm{mm} ; \mathrm{LAN} /(\mathrm{LP}+\mathrm{LE})=0.42 \pm 0.01 ; \mathrm{WP} / \mathrm{LP}=1.33 \pm 0.05$; $\mathrm{LE} / \mathrm{LP}=2.13 \pm 0.10 ; \mathrm{LE} / \mathrm{LSP}=8.99 \pm 0.81$.

Paratypes very variable in color and in size (Fig. 19), but very similar to the holotype in shape and sculpture. Chromatically they show often dorsal integument clearly bicolored, with variations from reddish brown to dark brown. Female generally bigger than male (Fig. 19); middle tibiae generally narrower, without elongate sensorial hollow on inner side. Spermatheca (Fig. 16) with basal part subcylindrical, distinctly tapered towards proximal end; distal part very developed, with collum and apical part not separate; ductus of spermatheca little elongate, uncoiled, ventrally inserted at basis of the basal part; styli and spiculum ventrale as in Figs 17-18.

Etymology. The species name was chosen to emphasize the strong wing reduction exhibited by this new species.

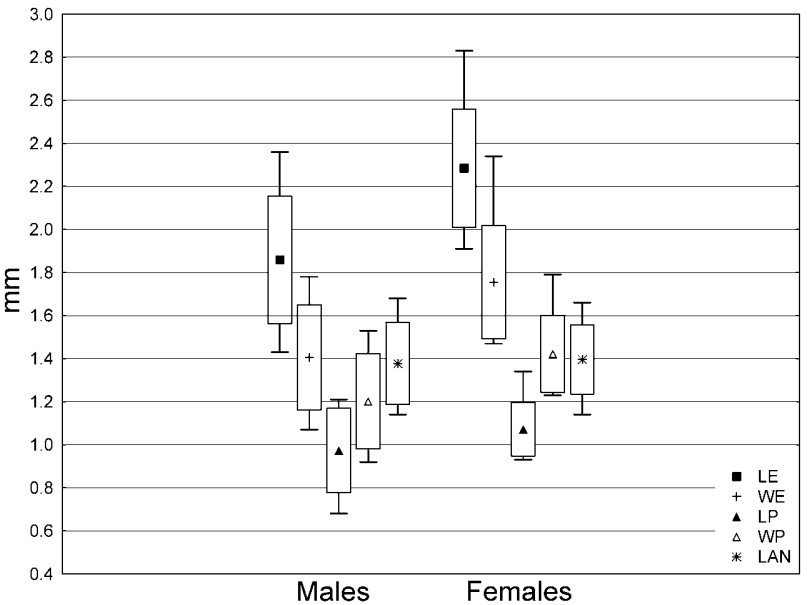

Fig. 19. Box-wiskers plots (mean, standard deviation, minmax) for the variables LE, WE, LP, WP and LAN in males and females of Afroaltica subaptera sp. n.

Geographical distribution. Republic of South Africa: Eastern Transvaal and Kwazulu-Natal provinces (Fig. 1).

Ecology. Afroaltica subaptera sp. n. was collected along road sides and forest edges, between 1200 and $1700 \mathrm{~m}$ of altitude, on Gramineae.

ACKNOWLEDGMENTS. We are very grateful to our colleagues M. Uhlig and H. Wendt (ZMHB) who enabled us to study the valuable material preserved in their institutions. Moreover, special thanks go to our friend E. Colonnelli for having provided us with material collected during his expeditions to South Africa. This paper was supported by a grant from the Ministero dell'Istruzione, dell'Università e della Ricerca (PRIN 2004057217 "Zoogeography of Mediterranean-southern African disjunct distributions by a multimethod approach").

\section{REFERENCES}

FurTh D.G. \& SuZUKI K. 1994: Character correlation studies of problematic genera of Alticinae in relation to Galerucinae (Coleoptera: Chrysomelidae). In Furth D.G. (ed.): Proceedings of the Third International Symposium on the Chrysomelidae, Beijing, 1992. Backhuys Publishers, Leiden, pp. $116-135$.

Furth D.G. \& Suzuki K. 1998: Studies of Oriental and Australian Alticinae genera based on the comparative morphology of the metafemoral spring, genitalia, and hind wing venation. In Biondi M., Daccordi M., Furth D.G. (eds): Proceedings of the Fourth International Symposium on the Chrysomelidae. Proceedings of XX I.C.E. Firenze, 1996. Museo Regionale di Scienze Naturali, Torino, pp. 91-124.

Latreille P.A. 1829: Crustacés, arachnides et partie des insectes. In Cuvier G. (ed.): Le Règne animal distribué d'après son organisation, pour servir de base à l'histoire naturelle des animaux et d'introduction à l'anatomie comparée. Vol. 4. 2nd ed. C.L.C.F.D., Déterville, Paris, 584 pp.

Petitpierre E. 2000: Coleoptera, Chrysomelidae I. In Ramos M.A. et al. (eds): Fauna Iberica. Vol. 13. Museo National de Ciencias Naturales, CSIC, Madrid, 521 pp.

SCHERER G. 1961: Bestimmungsschlüssel der Alticinen-Genera Afrikas (Col. Phytoph.). Entomol. Arb. Mus. Georg Frey 12: 251-289.

Received April 12, 2006; revised and accepetd October 3, 2006 